\title{
The Influence of Guided Discovery Learning Assisted by Fraction Wheel to Student Critical Thinking
}

\author{
Eni Rulita ${ }^{1}$, Akhmad Jazuli ${ }^{2}$ \\ $\left\{\underline{\text { enirulita@gmail.com }}\right.$, $\underline{\text { ahmadjazuli.ump@gmail.com }}{ }^{2}$ \} \\ SD Negeri 4 Pengalusan, Purbalingga \\ Postgraduate Basic Education, Universitas Muhammadiyah Purwokerto
}

\begin{abstract}
This study aims to determine the influence of Wheel-assisted Guided discovery learning model on students'critical thinking skills. This study uses a quasiexperimental post-test only control group design. The population of this research is the fifth grade of elementary schools in the Gajah Mada group consists of 8 schools. The subjects involved 17 grade fifth students at SDN 4 Pengalusan as an experimental class and 20 grade fifth students as control classes. Data collection instruments re tests of critical thinking skills. Data analysis used t-test technique (independent sample ttest).The study concluded that fraction wheel assisted guided discovery learning models affect students critical thinking skills.
\end{abstract}

Keywords: guided discovery learning,critical thinking, fraction wheel, elementary school

\section{Introduction}

Critical thinking skills are needed to face the challenges of the 21st century. Based on observational data of several teachers, they show that students' critical thinking skills arelow, this is indicated by the skill to understand problems, express, or write down problems that are being faced or presented by the teacher, providing a way to overcome a problem. Problem based on explicit knowledge, gathering information from various sources, arguinglogicallywithout coercion when discussing, assessing the learning outcomes themselves, assessing the learning outcomes of other groups, and drawing conclusions are still low.

To build critical thinking skills, teachers can provide learning experiences by designing the learning process. The teacher designs learning by providing problems that stimulate students' thinking skills and analytical skills [1].

Critical thinking is a reflective review that focuses on deciding what to believe and do [2]. Critical thinking skills include the ability to analyze, synthesize, information that can be trained, studied, and mastered [3]. Emily stated that "critical thinking includes the skill component of analyzing argument, making inferences using inductive or deductive reasoning, judging or evaluating and making decisions or solving problems " [4]. This definition means that critical thinking includes the skills components to analyze arguments, make conclusions, use deductive and inductive reasoning, assessments, evaluate and make problem solving decisions.

Critical thinking can be trained through guided discovery learning. This method involves students finding their meaning, organizing, and constructing ideas [5].

This learning model is proven to be successful in improving students' conceptual understanding [6]. The Guided Discovery Learning model is a learning model that encourages 
students to be motivated to answer open and in-depth questions from the teacher. This model also encourages students to understand the topic of the lesson and increase motivation to learn, so this model is expected increase students' understanding of concepts and can also improve critical thinking skills.

Guided discovery is a teaching method that regulates teaching so that children acquire previously unknown knowledge not through notification, partly or being discovered by themselves [7]. In the discovery method, the students did not know what find the final form. Discovery learning is a learning process that allows students to discover for themselves through a series of concrete experiences [8]. Even what is learn is presented in a non-final form, students are require to carry out several mental activities before it is accept into their cognitive structure in learning with the guided discovery. The teacher leads to the subject matter. The guided given by the teacher can be in the form of instructions, directions, questions, so that students are expect to be able to conclude (generalize) according to the teacher's design.

The steps for Guided Discovery Learning: Stimulus, asking questions, or encouraging students to observe pictures or read books about the material. Statement of the problem, students are guided to think criticallyto identify as many problems as possible that are relevant to the subject matter, then selecting and formulating them in the form of a hypothesis. Data collection is students are guided to think criticallyto collect information. Data processing is students are guided to think critically processing data to find the concept of problem solving with the help of the fraction wheel. Verify,students are guided to think criticallyto associate with a careful examination to prove the correctness of the hypothesis. Generalization, students are guided to think criticallyto related to concludingthe learning process that has been carried out [9].

Impalements guided discovery needs to be supported by the media able bridge dun it concretely with abstract mathematical concepts. according to media, education is an object that can be sense, especially sight and hearing (teaching aids) both inside and outside the classroom, which is used as a connecting aid (communication medium) in the process of teaching and learning interactions to increase the effectiveness of student learning outcomes. [10].

The fraction wheel is use as a tool in stimulation syntax, data processing. The fraction wheel helps students think critically about the size of each fraction, and the formation of the idea of value fractions. The fraction wheel value is use as the basis for discovering the concept of calculating the addition and subtraction of fractions. The fraction wheel is use to support conclusions with logical arguments.

\section{Research methods}

This study used a quasi-experimental method in the form of Post-test Only Control Group Design [11]

The subjects of this study involved 17 fifth grade students of Elementary School 4 Pengalusan as the experimental class and 21 students of class V Elementary School pengalusan as the control class. Sampling was carried out random, by drawing lots from the entire population, namely class V Elementary School in the Gajah Mada cluster.

The data collection tool was in the form of test questions measuring critical thinking skills. Before use, the instrument is validated by an expert. The validity test of the instrument items was using Pearson's Product Moment. The effect of the guided discovery model can we will see from the difference in the post-test results between the experimental class and the 
control class. Statistical calculations using a different test (t-test) independent sample test. The t-test was carried out after the normality, homogeneity test with a significance level of 0.05 .

\section{Results and Discussion}

Instruments to measure critical thinking skills before use are get validation experts. The validation results show 3.84 (0.00-4.00), which shows anexcellent category.

The validity of critical thinking skills was test on 15 grade V SDN 3 Pengalusan children. The results of the validity trial were calculate using Pearson's Product Moment [12], showing five valid questions so that it can be used as a research instrument.

Data on students' critical thinking skills were collected using an instrument to test necessary thinking skills. The data were collected through a post-test experimental class using a guided discovery model with a control class using conventional methods.

The first stage is the pre-test of data analysis, namely the normality and homogeneity test. The prerequisite test of this research includes the Kolmogorov Smirnov normality test with $\alpha=0.05$ and the homogeneity test using the Lavene test using SPSS V.22.

Table 3.2 homogeneity test Test of Homogeneity of Variances

\begin{tabular}{rrrr}
\hline df1 & df2 & Sig. \\
\hline 1 & 37 & .740 \\
\hline
\end{tabular}

From table 3.2 above, the sig value $>0.05$ means that $\mathrm{H}_{0}$ is accepted. So, it can be concluded that there is no difference in variance or that all data groups come from a homogeneous population. The data is normal and homogeneous, then the next step is to analyze the data using an independent sample t-test.

Tabel 3.3 Independent Sample Test

\begin{tabular}{|c|c|c|c|c|c|c|c|c|c|c|}
\hline & & $\begin{array}{r}\text { Leve } \\
\text { Tes } \\
\text { Equal } \\
\text { Varic }\end{array}$ & $\begin{array}{l}\text { ne's } \\
\text { for } \\
\text { ity of } \\
\text { nces }\end{array}$ & \multicolumn{7}{|c|}{ t-test for Equality of Means } \\
\hline & & \multirow[t]{2}{*}{$\mathrm{F}$} & \multirow[t]{2}{*}{ Sig. } & \multirow[t]{2}{*}{$\mathrm{t}$} & \multirow[t]{2}{*}{ df } & \multirow[t]{2}{*}{$\begin{array}{l}\text { Sig. (2- } \\
\text { tailed) }\end{array}$} & \multirow[t]{2}{*}{$\begin{array}{c}\text { Mean } \\
\text { Difference }\end{array}$} & \multirow[t]{2}{*}{$\begin{array}{l}\text { Std. Error } \\
\text { Difference }\end{array}$} & \multicolumn{2}{|c|}{$\begin{array}{l}95 \% \text { Confidence } \\
\text { Interval of the } \\
\text { Difference }\end{array}$} \\
\hline & & & & & & & & & Lower & Upper \\
\hline \multirow{2}{*}{$\begin{array}{l}\text { math } \\
\text { learning } \\
\text { outcomes }\end{array}$} & $\begin{array}{l}\text { Equal } \\
\text { variances } \\
\text { assumed }\end{array}$ & .112 & .740 & -9.010 & 37 & .000 & -32.90909 & 3.65259 & -40.30995 & -25.50823 \\
\hline & $\begin{array}{l}\text { Equal } \\
\text { variances not } \\
\text { assumed }\end{array}$ & & & -8.961 & 33.818 & .000 & -32.90909 & 3.67260 & -40.37420 & -25.44398 \\
\hline
\end{tabular}

Based on the results of the t-test above showed that the group of students given the guided discovery learning model obtained sigscore of $<\alpha, 0.00<0.05$. This means that $\mathrm{H}_{0}$ is rejected and $\mathrm{H}_{1}$ is acceptedmeaning that there is an influence onlearning the guided discovery model on students' critical thinking skills.

The results showed that there were differences in critical thinking skills in the math's eyes of students who used guided discovery models with students using conventional learning methods. The average post-test results of students use the guided discovery method are 55 while the average post-test of students using conventional method is 88 while the $t$-test shows the results of sign $0.00<0.005$ mean that there are differences in students who do learning 
using the guided discovery method compared to students who do learning with conventional methods. So, it can be concluded that there is an influence of the guided discovery model on students' critical thinking skills.

Improving of students' critical thinking skills in the guided discovery learning model is because the stakes in the method lead students to perform step by step critical thinking. Studentswho do discovery cleavage conduct investigations, collect data, analyze data, verify data, formulate conclusions, or find concepts, and present reasons to support conclusions[13].

The success of the guided discovery methodsis assisted byfraction wheel, the function of the fraction wheels, especially in stage of data analysis, verification, formulating conclusions and,logical arguments. The fraction wheel is use to support arguments regarding findings logically.

They are learning by guided discovery method conditioning students to conduct critical thinking processes [14]. By doingthe thought process to find concepts, understanding the concepts obtained by students is more meaningful. The obstacles in learning guided discovery are the varied abilities of students.so, the level difficulty faced by students is diverse in finding concepts. Another obstacle is that learning mathematics with the guided discovery method is new learning for students, so that at the first meeting, students feel confused and have difficulty because usually, the teacher explains the material to be studied and gives examples of problems and solutions.

In the process of finding the concept, students get help from the teacher.The assistance provided using scaffolding techniques. The Scaffolding technique is a technique toservice students while the students have difficulty above his ability to solve problems, among others in the form of asking questions and giving hints, questions presented by the teachers in the form of the question is a continuation of the question outline in the student worksheet. The assistance provided not for individuals but groups. Based on the observations, it isobtainedthat, the assistance provided by teacher varies from school to school, high-level schools the assistance providedtends to be less than medium and low-level schools.

Whether or not students succeed in finding the concept depends largely on the questions presented in the Student Worksheet and the oral questions the teacher gives to provoke students into thinking. The questions asked should be affordable to the students' mind so that students easily understand and construct concepts, and learn to find problem-solving. It is done, so as not to make students fail in finding concepts or so that students lose the spirit of learning.

\section{Conclusion}

Based on the results of data analysis in this study, it can be concluded that mathematics learning with a guided discovery modelis better than conventional learning models in improving students' critical thinking skills. From the results of the study, researchersrecommend implementing a guided discovery learning model so that students' critical thinking skills improve so that students through teacher guidance can find conceptsand learningbecomes more meaningful.

\section{References}

[1] Nafiah, NY 2014. Application of Problem Based Learning Model to Improve Critical Thinking Skills and Student Learning Outcomes. Journal of Vocational Education 4 (1) pp. 125-143.

[2] Fisher, Alec. An introduction to critical thinking. Erlangga:2008

[3] Redecker, C., et al. The Future of Learning: preparing for change. Luxembourg: PublicationsOffice of the European Union. 2011 
[4] Emily. Critical Thinking: A Literature Review.Research Report.Always Learning Person. 2010

[5] Mustikawati, F., \&Nurita, T. Application of Guided Discovery Model to Improve Students' Science Literacy on Mirror Material. Pensa.2021. E-Journal of Science Education, 9 (1), 110-118. Retrieved

[6] Suryanti, S. Increased self-confidence and problem-solving abilities of students in discrete mathematics courses through discovery learning. 2015.DIDAKTIKA: Journal of Educational Thought, 22 (1), 64-73.

[7] Ruseffendi, ET: Introduction to Helping Teachers Develop Competencies in Teaching Mathematics to improve CBSA.Bandung: Tarsito. 2006

[8] Hudojo, H.: Curriculum Development and Mathematics Learning. Malang: UM PRESS. 2005

[9] Nursanty, UO, and ZahraChairani. Development of Student Worksheets (LKS) of Guided Discovery Based Learning Circle Material for Class VIII Junior High School Students 2016. Journal of Mathematics Education. Volume 2. No 1. ISSN 2442-3041

[10] Nunuk, S., Setiawan, A. Innovative Learning Media and Its Development .219

[11] Sugiyono. Quantitative Research Methods, Qualitative and R \& D. Bandung: Afabeta 2011

[12] Firdaus, Zamal. Correlation between Taxation Technical Training, Tax Auditor Experience and Motivation with Tax Auditor Performance at the Tax Office in West Jakarta. Faculty of Economics and Social Sciences, SyarifHidayatullah State Islamic University Jakarta 2009

[13] Widura, SH .EffectOf Guided Discovery L earning I n C critical T thinking S kills ofstudent Class X SMA Negeri 8 Surakarta Academic Year 2014/20152015..Bio-Pedagogy 4 (2). ISSN: 22526897

[14] Rochaminah, S. Using Invention Methods to Improve Teacher Students' Mathematical Thinking Ability. 